\title{
Mide Büyük Kurvaturda Dev Gastrointestinal Stromal Tümör Giant Gastrointestinal Stromal Tumor in Stomach Curvatura Major
}

\author{
Bartu Badak \\ Eskişehir Osmangazi Üniversitesi Tıp Fakültesi Genel Cerrahi Anabilim Dalı, Eskişehir, Türkiye
}

Öz: Gastrointestinal stromal tümörler interstisyel Cajal hücrelerinden köken alan sindirim sisteminin en sık karşılaşılan mezenkimal tümörleridir. Sindirim sisteminde en sık yerleştiği bölge mide olmakla beraber çok az oranda da olsa gastrointestinal sistem dışındaki organlarda da bildirilmiştir. Genellikle 4. dekad sonrası görülmekle beraber ortalama tanı yaşı 60’tır. Semptomları genellikle karın ağrısı, şişkinlik, yutma güçlüğü, meteorizm gibi tümöre özgü olmayan özelliklerdir. Bu sunumda mideden orijin alan yaklaşık $20 \mathrm{~cm}$ 'lik dev gastrointestinal stromal tümör olgusu sunulmuştur.

Anahtar Kelimeler: gastrointestinal stromal tümör, dev, mide

Badak B. (2017). Mide büyük kurvaturda dev gastrointestinal stromal tümör, Osmangazi Tip Dergisi, 39(2):51-55 DOI: $10.20515 /$ otd.302087.

\begin{abstract}
Gastrointestinal stromal tumours that arise from interstitial cell of Cajal in the gastrointestinal tract are the most common mesenchymal tumours. These tumours are usually localised in the stomach in gastrointestinal system, although it is rarely reported to be encountered in other organs other than gastrointestinal tract. It's usually seen in the 4th decade, at a mean age of 60 years. The symptoms are usually abdominal pain, bloating, dysphagia, meteorism that are not spesific for tumour. In this presentation a giant gastrointestinal stromal tumour that originated from stomach is performed.
\end{abstract}

Keywords: gastrointestinal stromal tumour, giant, stomach

Badak B. (2017). Giant gastrointestinal stromal tumor in stomach curvatura major, Osmangazi Journal of Medicine, 39(2): 51-55. DOI: $10.20515 /$ otd.302087. 


\section{Giriş}

Gastrointestinal sistem stromal tümörlerinin tanımı ilk defa 1983 yılında Mazur ve Clark tarafından yapılmışıır (1). İntestinal myenterik pleksus içinde var olan ve barsak peristaltizmini düzenlemekle görevli olan interstisyel Cajal hücrelerinin neoplastik transformasyonundan kaynaklandığ 1 düşünülen mezenkimal tümörlerdir (2). Tüm gastrointestinal sistem tümörlerinin \%1'inden az kısmını oluşturan bu tümörler en çok sırası ile mide (\%60-70), ince barsak (\%20-30), kalın barsak (\%18) ve özefagusta (\%1) görülmektedir (3). Lokalizasyonlarına göre endoluminal, eksoluminal, intramural ve mikst tip olarak siniflandırılırlar (3). Genellikle 4. dekad sonrası görülmekle beraber ortalama tanı yaşı 60'tır. Klinik prezentasyonu sıklıkla karın ağrısı, şişkinlik, yutma güçlüğü, karında ele gelen kitle, anemi, dispeptik şikayetlerdir (4). Bu tümörlerin en önemli malignensi özelliği komşu organlara yayılım ve lenf nodu metastazıdır (5). Metastatik olmayan hastalıkta primer tedavi cerrahidir (4). Çalı̧̧mamızda karında şişkinlik ve yutma güçlügü nedeni ile opere edilen 71 yaşında bayan hastamızın cerrahi tedavi ve takip sonuçlarını sunmayı amaçladık.

\section{Olgu Sunumu}

Yetmiş bir yaşında bayan hasta yemeklerden sonra oluşan şişkinlik ve ara ara oluşan yutma güçlüğü nedenli kliniğimize başvurdu. Hastanın muayenesinde akut batın hali mevcut değildi. Epigastrik minimal hassasiyeti bulunan hastanın sol üst kadran muayenesinde ele gelen kitle mevcuttu. Laboratuvar bulguları normal olan hastanın öyküsünden bu şikayetleri yaklaşık 5 yıldır çektiği öğrenildi. Ek dahili problem olarak hipertansiyon hikayesi ve buna bağl1 ilaç kullanımı mevcuttu. Hastaya etyolojiye yönelik çekilen tüm karın abdomen bilgisayarlı tomografide 'mide korpus düzeyinde yaklaşık $6 \mathrm{~cm}$ 'lik mide duvarını ilgilendiren ve mide içerisine protrüde görünümde, ekzofitik, $11 * 9,5 * 12 \quad \mathrm{~cm}$ boyutlarda, lobule konturlu, santrali düşük dansitede, yumuşak doku dansitesinde, kontrast tutulumu gösteren öncelikle GIST (gastrointestinal stromal tümör) ile uyumlu kitle lezyon' sonucu raporlandi. 'Hastanın uzak metastazı bulunmamaktaydı. Hastadan tanısal amaçlı biyopsi istendi. Girişimsel radyoloji bölümünce yapılan biyopsi sonucu ' gastrointestinal stromal tümör (GIST), mide' olarak sonuçlandı. Histopatolojik incelemede hücre subtipi ' iğsi' idi. 50 büyütme alanında 4 adet mitoz mevcuttu. Progresif hastalık riski orta derecede (\%10) olarak kabul edildi. Operasyona alınan hastaya yapilan eksplorasyonda kitlenin splenik fleksurada kolona, tabanda splenik arter ve vene, pankreasa yakın komşulukta, yüzeyde mide büyük kurvaturdan kaynak aldığ 1 ve mide içerisine 3-4 cm entegre olmuş yaklaşı $15 * 10 * 12 \mathrm{~cm}$ boyutlarında kistik, lobule kitle gözlemlendi. Etraf dokulardan ayrılan kitle, mideye de sleeve gastrektomi prosedürü uygulanarak total eksize edildi. Ameliyat sonrası 3. günde oral alım başlanan hasta; 7. günde şifa ile ayaktan taburcu edildi. Hastaya ameliyat sonrası medikal onkoloji kontrolü ve 3. ayda kontrol abdominal bilgisayarlı tomografi ve sintigrafi önerildi.

\section{Tartışma}

Gastrointestinal stromal tümörler interstisyel Cajal hücrelerinden köken alan sindirim sisteminin en sık karşıllaşılan mezenkimal tümörleridir (6). Tüm sindirim sistemi boyunca saptanabilmekle beraber en s1k midede ortaya çıkar (3). Tüm gastrointestinal sistem tümörlerinin \%1'inden azını, tüm mide tümörlerinin ise yaklaşık $\% 5$ 'ten az bir kısmını oluşturmaktadır (7). GIST'ler, KIT tirozin kinaz reseptörü içermeleri ile de diğer gastrointestinal mezenkimal tümörlerden ayrılan spesifik bir tümör grubu oluşturmaktadır. İmmünohistokimyasal olarak saptanan CD117 (c-kit) pozitifliği en spesifik ve en diagnostik kriter kabul edilmektedir. (8) Bizim olgumuzda da CD117 ve CD34 diffüz pozitifliği mevcuttu. SMA pozitif idi. GIST'ler histolojik olarak iğsi hücreli tip (bizim olgumuz), epiteloid tip, mikst tip olarak 3, lokalizasyon olarak endoluminal, eksoluminal, intramural ve mikst tip olark 4 gruba ayrılırlar (8). 

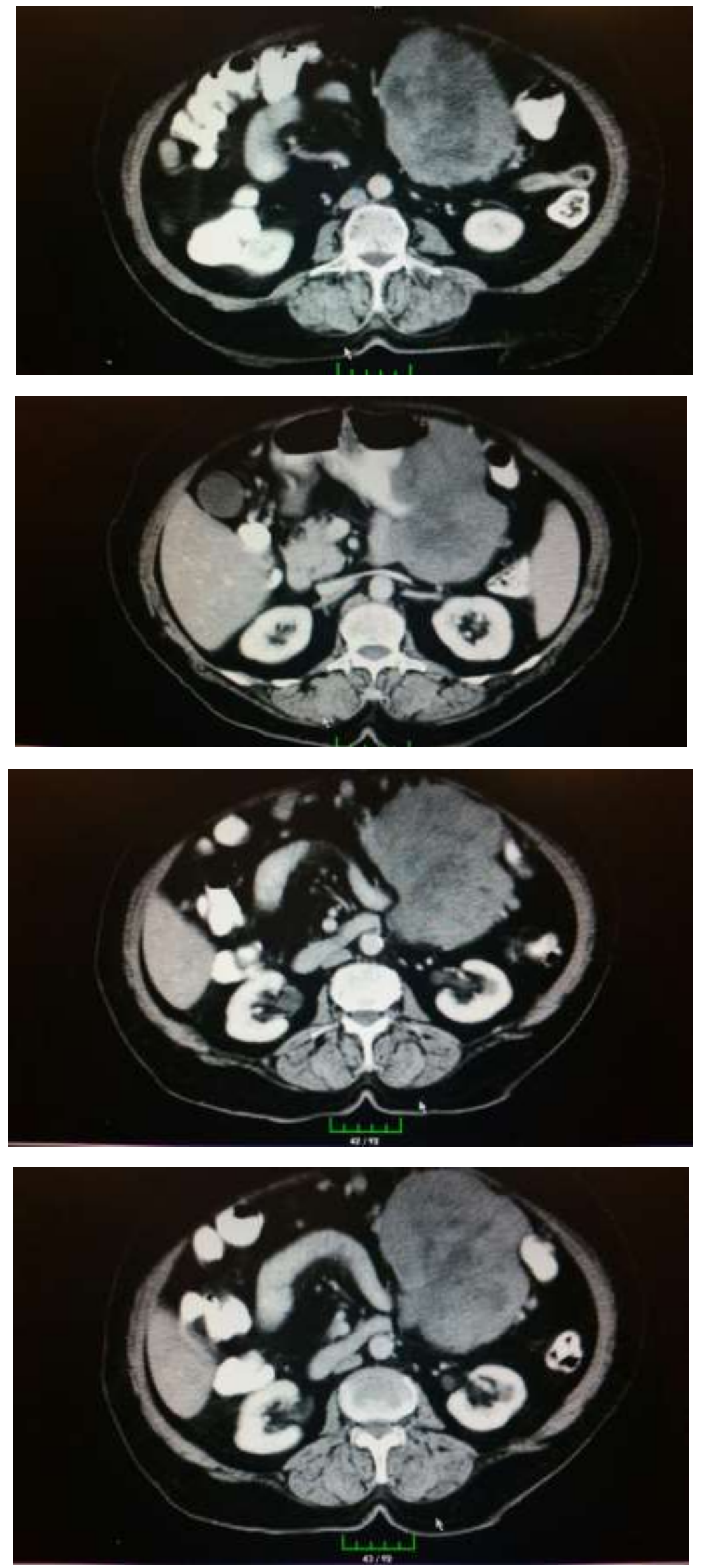

Resim 1-2-3-4: Gastrointestinal stromal tümör bilgisayarl tomografi görüntüleri 
Genelde asemptomatik seyreden GiST'ler büyüklüğü küçük olgularda başka nedenlerden dolayı yapılan cerrahilerde tesadüfi olarak saptanırlar. Semptomatik olanlar ise tümörün yerine ve boyutuna bağlı olarak karın ağrısı, kanama, şişkinlik, yutma güçlügüu, dispepsi, ele gelen kitle gibi şikayetlerle presente olabilirler (5).

GIST şüphesinde öncelikle fizik muayene ve hikaye değerlendirilmesi yapılmalıdır. Direkt grafi kalsifik komponent bulunan olgularda kullanışı olabilirken; bilgisayarlı tomografi ve MRI tümörün boyutları, lokalizasyonu, metastaz gibi koşulları ayırt etmede oldukça yararlıdır. Endoskopik incelemeler mide kaynaklı olduğu düşünülen olgularda kullanılabilmektedir. Kesin tanıy ameliyat öncesi koymanın tek yolu biyopsidir (9). Tümörün kapsül bütünlüğünün bozulması ve tümör ekimi gibi sebeplerden dolayı ince iğne aspirasyon biyopsisi önerilmese de bizim olgumuzda olduğu gibi kitlenin mide kaynaklı olduğu düşünülen olgularda ve irrezekable olduğu düşünülen olgularda tanı amaçlı biyopsi kaçınılmazdır (10). GIST'lerin malignite potansiyeli olduğu kabul edilir. Malignite potansiyelleri ise çok düşük, düşük, orta ve yüksek risk olarak kategorize edilir (11). Bizim olgumuzda da patoloji sonucu orta risk olarak belirtildi.

Gastrointestinal tümörlerde primer tedavi seçeneği cerrahidir. Amaç; negatif cerrahi sınır, tümörün rüptüre olmaması ve artık tümör bırakmamaktır. Tedavide bilinen kemoterapi ve radyoterapi protokollerinin yeri yoktur (12). Ancak cerrahiye uygun olmayan hastalarda, metastatik olgularda 'imatinib mesilat' pratik uygulamaya giren ilk hedef ajandır. Tedavinin takibi için abdominal tomografi ve sintigrafi önerilmektedir. Tümör direkt invazyon yapma eğiliminde olmakla beraber hematojen ve lanfatik yolla da az sayıda olgu gösterilmiştir. Rutin lenfadenoktomiye gerek yoktur (13).

\section{Sonuç}

Nonspesifik gastrointestinal sistem semptomları ile başvuran orta yaş erişkin hastalarda GíST hep akılda tutulmalı ve opere edilen hastalarda temiz bir cerrahi sağlanmalıdır.

Kisaltmalar

GIST: Gastrointestinal stromal tümör

MRI: Manyetik rezonans imajinasyon

\section{KAYNAKLAR}

1. Mazur MT, Clark HB. Gastric stromal tumors: Reappraisal of histogenesis. Am J Surg Pathol 1983;7:507-19.

2. Kindblom LG, Remotti HE, Aldenborg F, MeisKindblom JM. Gastrointestinal pacemaker cell tumor (GIPACT): gastrointestinal stromal tumors Show phenotypic characteristics of the interstitial cells of Cajal. Am J Pathol 1998;152:1259-69.

3. Miettinen M, Lasota J. Histopathology of gastrointestinal stromal tumor. J Surg Oncol 2011;104:865-873

4. Yamamoto H, Kojima A, Miyakasa Y, Imamura M, Nakamura N, Yao T, Tsuneyoshi M, Oda Y Prognostic impact of blood vessel invasion in gastrointestinal stromal tumor of the stomach. Hum Pathol. 2010 Oct;41(10):1422-30.

5. Miettinen M, Monihan JM, Sarlomo-Rikala M, et al. Gastrointestinal stromal tumours/smooth muscle tumours (GISTs) primary in the omentum and mesentery: clinicopathologic and immunohistochemical study of 26 cases. Am J Surg Pathol 1999;23:1109-1118.

6. Büyükaşık O, Hasdemir OA, Dirican A, Çöl C. Gastrointestinal stromal tümörler. İnönü Üniversitesi Tıp Fakültesi Dergisi 2009;16:227-32.

7. Naguib SF, Zaghloul AS, El Marakby H. Gastrointestinal stromal tumors (GIST) of the stomach: retrospective experience with surgical resection at the National Cancer Institute. J Egypt Natl Canc Inst 2008;20:80-9

8. Fletcher CD, Berman JJ, Corless C, Gorstein F, Lasota J, Longley BJ, Miettinen M, O'Leary TJ, Remotti H, Rubin BP, Shmookler B, Sobin LH, Weiss SW. Diagnosis of gastrointestinal stromal tumors: A consensus approach. Hum Pathol 2002;33: 459-465.

9. Pidhorecky I, Cheney RT, Kraybill WG, Gibbs JF. Gastrointestinal stromal tumors: Current diagnosis, biologic behaviour and management. Ann Surg Oncol 2000;(7):705-712. 
10. Dizdar O, Guler N. Gastrointestinal stromal tümörler ve imatinib tedavisi. Hacettepe Tip Dergisi 2004;35:87-91.

11. Miettinen M, El Rifai W, HL Sobin L, et al. Evaluation of malignancy and prognosis of gastrointestinal tumors: a review. Hum Pathol 2002;338:478-483.
12. Bucher P, Egger JF, Gervaz P, et al. An audit of surgical management of gastrointestinal stromal tumors (GIST). Eur J Surg Oncol 2006;32:310-4.

13. Demetri GD, von Mehren M, Blanke CD, et al. Efficiacy and safety of imatinib mesylate in advanced gastrointestinal stromal tumors. N Engl J Med 2002;(347):472-480. 